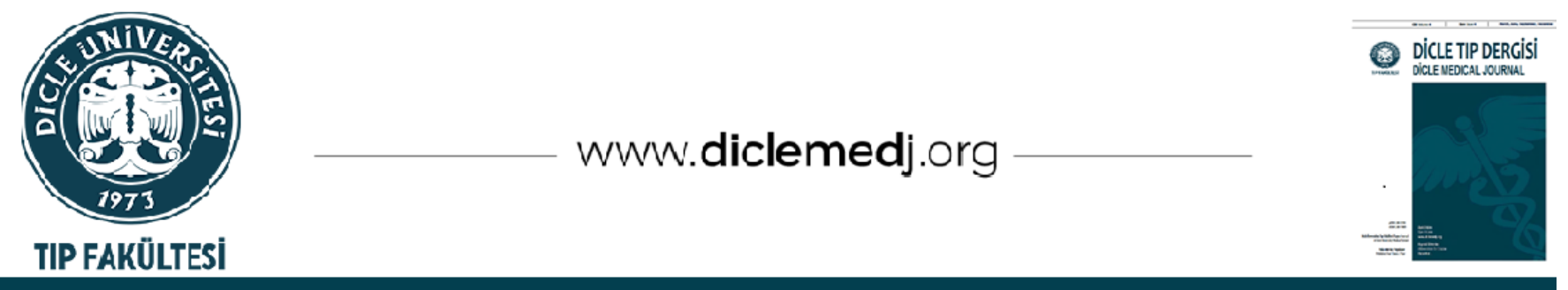

Original Article / Özgün Araştırma

\title{
The Effect of Health Problems at Birth on Breastfeeding: A Cross- Sectional Study in a Third Step Hospital
}

\author{
Hatice Tuba Akbayram 1 \\ 1 Department of Family Medicine, Gaziantep University Faculty of Medicine, Gaziantep, Turkey
}

Received: 20.10.2020; Revised: 29.11.2020; Accepted: 07.12.2020

\begin{abstract}
Objective: The health status at birth can affect infant's ability to start suckling and the breastfeeding process. The aim of this study is to compare the process of starting and continuing breastfeeding of healthy babies and infants born with health problems and also to evaluate the effect of health problems at birth on breastfeeding.

Method: 460 mothers with infants between 6-24 months of age who admitted to the pediatric outpatient clinics were enrolled in the study.

Results: It was found that $19.2 \%$ health problems at birth. Among healthy babies the rate of breastfeeding as first nutrition and breastfeeding in first hour after delivery was found to be $82 \%$ and $67 \%$ respectively. These rates were $49.5 \%$ and $32.3 \%$ in infants born with health problems, respectively $(\mathrm{p}<0.001)$. The rate of breastfeeding in healthy babies for the first six months of life was 39.9\% and this rate was very low in babies born with health problems (23.2\%) ( $\mathrm{p}<0.001$ ).It was found that $31.9 \%$ of infants born with health problems were feed by formula in the first month and $67 \%$ within six months. In the study, $59.9 \%$ of healthy babies and $39.6 \%$ of babies born with health problems continued to receive breast milk $(\mathrm{p}<0.001)$.

Conclusions: It was found that being born with health problems delays the time to start breastfeeding, increases the risk of feeding with formula in the first month and in the first six months of age, and adversely affects the continuation of breastfeeding.
\end{abstract}

Keywords: Breast milk, born with health problems, breastfeeding

DOI: 10.5798/dicletip.850402

Correspondence / Yazışma Adresi: Hatice Tuba Akbayram, Gaziantep University, Faculty of Medicine Department of Family Medicine 27600 Gaziantep, Turkey e-mail: tubaakbayram@gmail.com 


\section{Doğumda Sağlık Problemlerinin Anne Sütü Emme Üzerine Etkileri: 3.basamak Bir Hastaneden Kesitsel Çalışma}

$\ddot{0} \mathbf{z}$

Amaç: Bebeklerin doğum anındaki sağlık durumları, emmeye başlama yeteneklerini ve emzirme sürecini etkileyebilir. Bu çalışma sağlıklı doğan ve sağlık problemiyle doğan bebeklerin emzirmeye başlama ve devam sürecini karşılaștırmak ve sağlık problemiyle doğmanın emzirmeyi nasıl etkilediğini değerlendirmek amacıyla yapılmıştır.

Yöntemler: Bu kesitsel çalışma Şubat 2019-Mayıs 2019 tarihleri arasında Gaziantep Üniversitesi Tıp Fakültesi Hastanesinde yapılmıştır. Çalışmaya pediatri polikliniklerine başvuran 6-24 ay arasında olan bebeği olan 460 anne dahil edilmiştir. Veriler 22 sorudan oluşan anket formu yüz yüze görüşme tekniği ile toplanmıştır.

Bulgular: Bebeklerin \%49,8' inin sezaryenle, \%15,2'sinin prematüre, \%17,2'sinin düşük doğum ağırlıklı (<2500 gr) ve \%19,2'sinin doğum anında sağlık problemi olduğu bulundu. Sağlıklı olarak doğan bebeklerin ilk besin olarak ve ilk bir saatte anne sütüyle beslenme oranı sırasıyla \%82 ve \%67 olarak bulundu. Sağlık problemiyle doğan bebeklerde bu oranlar sırasıyla \%49,5 ve \%32,3 olup anlamlı olarak düşüktü $(\mathrm{p}<0.001)$. Sağlıklı doğan bebeklerin ilk altı ay sadece anne sütüyle beslenme oranı \%39,9 olup bu oran sağlık problemiyle doğan bebeklerde $(\% 23,2)$ oldukça düşüktü $(\mathrm{p}<0.001)$. Sağllk problemiyle doğan bebeklerin \%31,9'una ilk bir ay içerisinde ve \%67'sine altı aydan önce formül mama verildiği bulundu. Biberon kullanımı sağlık problemiyle doğan bebeklerde $(\% 73,6)$ daha yaygın olup, emzik kullanımında gruplar arasında anlamlı fark bulunmadı. Çalışmada sağlıklı doğan bebeklerin \%59,9'unun, sağlık problemiyle doğan bebeklerde \%39,6'sının anne sütü almaya devam ettiği bulundu. ( $\mathrm{p}<0.001)$

Sonuç: Sağlık problemiyle doğmanın anne sütüyle beslenmeye başlama zamanını geciktirdiği, ilk bir ay içerisinde ve ilk altı ay içerisinde formül mamayla beslenme riskini arttırdığı, emzirmeye devam etmeyi olumsuz etkilediği bulunmuştur. Sağlık problemiyle doğan bebeklerin annelerine, anne sütüyle beslenmeye başlama ve devam sürecinde sağlık profesyonelleri tarafından özel olarak eğitim, yardım ve destek verilmelidir.

Anahtar kelimeler: Anne sütü, sağlık problemiyle doğma, emzirme.

\section{INTRODUCTION}

Breastfeeding practices, such as starting breastfeeding early and nutrition with only breast milk, play key roles in decreasing childhood morbidity and mortality ${ }^{1}$. Therefore, the World Health Organization (WHO) suggests initiation of breastfeeding within the first 1 hour after birth, nutrition with breast milk only for the first 6 months of life and continuation of breastfeeding up to 2 years of age along with supplementary food ${ }^{2,3}$. In the initiation and continuation of breastfeeding, many factors about mothers, babies and environments play roles. These include demographic variables of mothers (age, education, income, marital status, ethnical origin, other children in the family, mother's working conditions, period of maternity leave), perception of milk sufficiency, practices in hospitals and newborn unit, and educational and supportive interventions to mother about breastfeeding 4 .

Features of babies and their health status are also of significance for breastfeeding. The health status of babies at the time of birth, birth weight, age of pregnancy and medications used during pregnancy can influence the ability to start and continue breastfeeding in an effective way ${ }^{5}$.Many newborns, who are followed up and treated in the newborn care unit due to prematurity and other diseases cannot be breastfed directly. In such situations, mothers are required to ensure and maintain milk production via breast pumps ${ }^{6}$. A certain proportion of these babies can be fed with milked breast milk via methods such as feeding with a nasogastric tube, an orogastric tube, a syringe, a dropper and a cup 7 .

Many studies were conducted on determining the factors that influence the initiation and 
continuation of breastfeeding of healthy babies and demonstrating positive health results of breastfeeding. Studies that evaluate the breastfeeding in babies with health problems and the effects of health problems in breastfeeding are limited. Knowing how being born with health problems affects breastfeeding will ensure that more attention is paid to high-risk mother/baby pairs as well as providing information and support. This study was conducted in a tertiary level hospital to compare the initiation and continuation of breastfeeding in babies who were born healthy and who were born with health problems, and to evaluate how being born with health problems affect breastfeeding.

\section{METHODS}

This cross-sectional study was conducted in the Education and Research Hospital in the Faculty of Medicine at Gaziantep University between February 2019 and May 2019. Ethical committee approval was obtained from the Faculty of Medicine at Gaziantep University prior to the study (Decision no: 2019/18).

Medicine Education and Research Hospital at Gaziantep University is one of the prominent healthcare institutions, which also provides healthcare services for patients coming from other cities in the vicinity. In this study, 460 mothers were included as participants, who applied to the pediatrics polyclinic with 6-24 months old babies during the period when the study was conducted. The mothers accepted to participate in the study and answered all the questions in the questionnaires. The circumstances where breastfeeding was contraindicated for mothers and babies and mothers who were suggested not to breastfeed by their physicians due to their diseases and medications they used were excluded from the study.

The questionnaire prepared by the researchers consisted of 22 items. The first section of the questionnaire form included items regarding the demographic variables of mothers and babies (mother's age, education, income status, working status, number of children in the family, baby's age, gender, birth weight, delivery method, mother's health status at the moment of birth, birth week). The second section of the questionnaire included items regarding breastfeeding (the first food given after birth, time of the first breastfeeding, period of only breastfeeding, use of baby formula, feeding bottle and pacifier).

The relationships between two independent variables on the categorical measurement level were tested with Chi-square. As descriptive statistics, mean and standard deviation calculations were conducted for quantitative variables while numerical and percentage values were assigned for categorical variables. For the statistical analyses, SPSS 24.0 package software was used and $\mathrm{p}<0.05$ was regarded as the statistical significance.

\section{RESULTS}

Of the 460 mothers included in the study, 269 (58.5\%) were between 25 -35 years old while a majority $(82.6 \%)$ was not working. $74.3 \%$ of the mother had more than one child while $63.3 \%$ had education status lower than high school and most of them (82.6\%) lowmoderate income level. The most participated in the study had babies who were between 624 months old (mean $13.08 \pm 5.03$ ) and $52 \%$ of the babies were males. $49.8 \%$ of the babies were born via caesarian section and $15.2 \%$ were born prematurely (before the 37th week of pregnancy). $78 \%$ of the babies (359) had birth weights between 2500-4000 g while $17.2 \%$ were born below 2500 g. When the health status at birth was investigated, it was determined that $19.8 \%$ of the babies (91) had health problems. The demographic variables of mothers and babies were presented in Table 1 . 
Table I: Demographic variables of mothers and babies

\begin{tabular}{|c|c|c|c|}
\hline \multicolumn{4}{|c|}{ Demographic variables of mothers and babies } \\
\hline \multicolumn{2}{|l|}{ Variables of Mothers } & \multirow{2}{*}{$\begin{array}{l}\mathbf{n} \\
115\end{array}$} & \multirow{2}{*}{\begin{tabular}{|l|}
$\%$ \\
25.0
\end{tabular}} \\
\hline \multirow{3}{*}{ Age } & Younger than 25 & & \\
\hline & 25-35 years old & 269 & 58.5 \\
\hline & Older than 35 & 76 & 16.5 \\
\hline \multirow{5}{*}{ Education Status } & Did not study & 29 & 6.3 \\
\hline & Primary school & 144 & 31.3 \\
\hline & Secondary school & 118 & 25.7 \\
\hline & High school & 107 & 23.3 \\
\hline & University & 62 & 13.5 \\
\hline \multirow{2}{*}{ Working Status } & Housewife & 380 & 82.6 \\
\hline & Working & 80 & 17.4 \\
\hline \multirow{3}{*}{ Income Status } & Low income & 125 & 27.2 \\
\hline & Moderate income & 255 & 57.4 \\
\hline & High income & 80 & 17.4 \\
\hline \multirow{3}{*}{ Number of Children } & 1 & 118 & 25.7 \\
\hline & 2 & 161 & 35.0 \\
\hline & 3 and more & 181 & 39.3 \\
\hline \multicolumn{4}{|l|}{ Variables of Babies } \\
\hline \multirow{2}{*}{ Sex } & Male & 239 & 52.9 \\
\hline & Female & 221 & 48.0 \\
\hline $\begin{array}{l}\text { Age } \quad \text { (month) } \\
\text { mean } \pm \text { SD }\end{array}$ & $13.08 \pm 5.03$ & & \\
\hline \multirow{2}{*}{ Type of Birth } & Normal & 231 & 50.2 \\
\hline & Caesarian Section & 229 & 49.8 \\
\hline \multirow{2}{*}{ Time of Birth } & Normal-late & 379 & 82.4 \\
\hline & Early & 81 & 17.6 \\
\hline \multirow{3}{*}{ Birth Weight } & Less than 2500 & 94 & 20.4 \\
\hline & $2500-3999 \mathrm{~g}$ & 344 & 74.8 \\
\hline & $4000 \mathrm{~g}$ and higher & 22 & 4.8 \\
\hline \multirow[b]{2}{*}{ Health Status at Birth } & Healthy & 361 & 78.5 \\
\hline & $\begin{array}{l}\text { Presence of Health } \\
\text { Problem }\end{array}$ & 91 & 19.8 \\
\hline
\end{tabular}

In the study, the rate for being fed by breastfeeding as the first food was $81.6 \%$ in the babies who were born healthy while the rate for being fed by breastfeeding in the first hour was $66.4 \%$. In the babies who were born with health problems, these rates were $48.4 \%$ and $31.9 \%$, respectively, which were significantly low $(\mathrm{p}<0.001)$. In this study, the rate for being fed only by breastfeeding was $39.8 \%$ in babies who were born healthy while it was $22 \%$ in babies who were born with health problems, which was significantly lower ( $\mathrm{p}<0.001) .31 .9 \%$ of the babies who were born with health problems had a time of being fed by breastfeeding less than 1 month. This rate was determined as $12.7 \%$ for healthy babies. The rate for being fed with baby formula before six months was $67 \%$ for babies who were born with health problems while this rate was higher (50.4\%) ( $\mathrm{p}=0.012)$. The rate of using feeding bottles was $73.6 \%$ in babies who were born with health problems while this rate was significantly higher $(63.1 \%)$ in babies who were born healthy $(\mathrm{p}=0.038)$. However, in terms of using pacifiers, no significant difference was determined between babies who were born healthy and who were born with health problems $(p>0.05)$. The data regarding the breastfeeding of babies who were born healthy and who were born with health problems were presented in Table 2 .

In this study, it was determined that 255 mothers continued breastfeeding while 186 mothers stopped breastfeeding as well as nineteen mothers (4.3\%) who never breastfed. In the study, it was determined that $59.9 \%$ of the babies who were born healthy (221) and $39.6 \%$ of the babies who were born with health problems (36) continued to be breastfed $(p<0.001)$. The reasons for the mother who stopped breastfeeding included the baby's rejection to be breastfed (27.4\%), lack of milk $(25.3 \%)$, belief that breast milk was not sufficiently provided (11.3\%) and disease of babies (10.8\%). The reasons for the mother who stopped breastfeeding were presented in Table 3. 
Table II: Breastfeeding status according to the health status of babies at birth

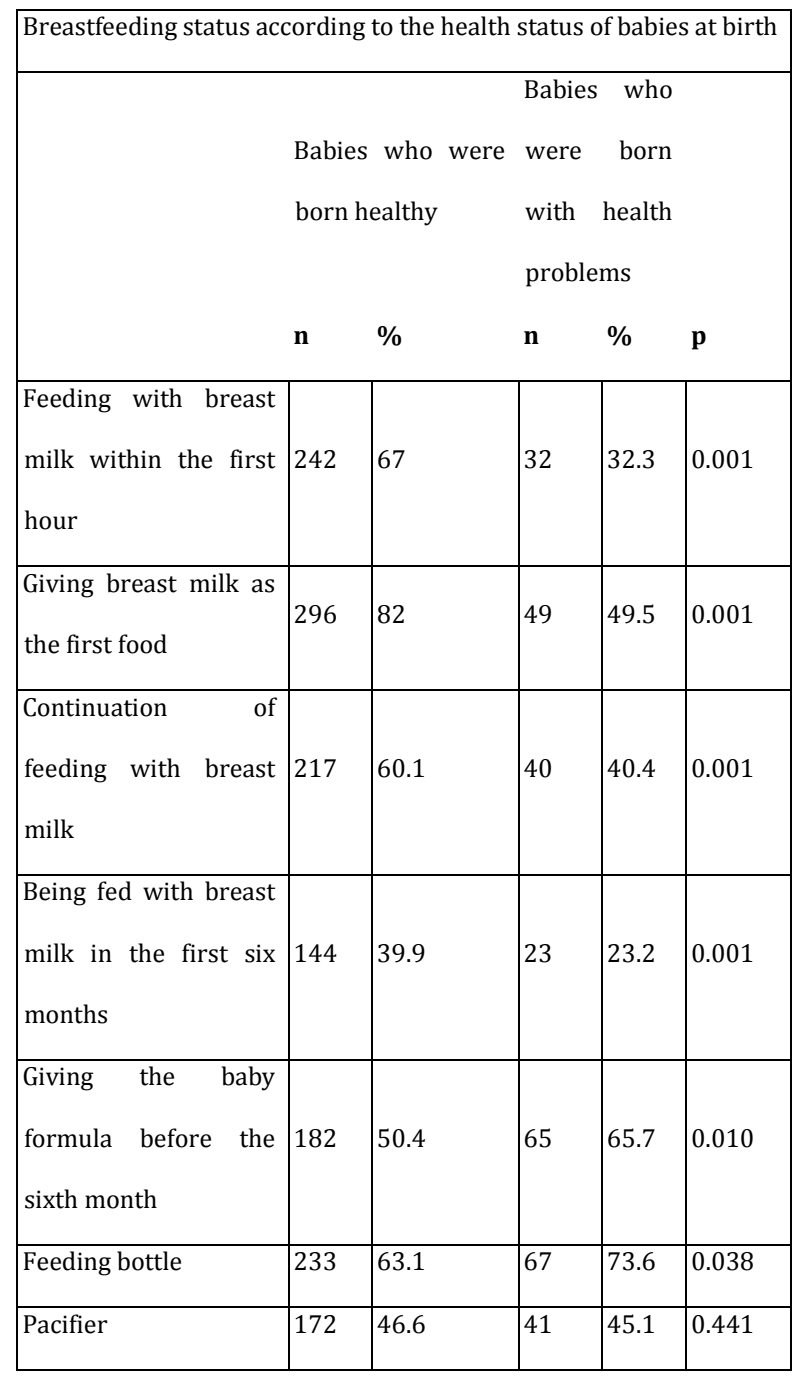

Table III: Reasons for mothers to stop breastfeeding

\begin{tabular}{|l|l|l|}
\hline Reasons for mothers to stop breastfeeding & n & $\%$ \\
\hline Rejection of baby to breastfeed & 51 & 27.4 \\
\hline Insufficient milk & 47 & 25.3 \\
\hline Believing that breast milk is not provided sufficiently & 21 & 11.3 \\
\hline Baby's illness & 20 & 10.8 \\
\hline Mother's illness or pregnancy & 14 & 7.5 \\
\hline Termination of breastfeeding because the baby does not & 14 & 7.5 \\
\hline eat anything else & & \\
\hline Breast and nipple problems & 11 & 5.9 \\
\hline Mother's working status & 8 & 4.3 \\
\hline Total & 186 & 100 \\
\hline
\end{tabular}

\section{DISCUSSION}

For the babies who were born healthy and on time, the period of starting to be breastfed and continuing to breastfeed can be a natural process. However, for babies, who were born early, and mothers, who had babies with health problems, the period of starting to be breastfed and continuing to breastfeeding is stressful and difficult ${ }^{8}$. A study conducted in the United States reported that $60 \%$ of the mothers did not achieve the breastfeeding aims they wished and their reasons for not breastfeeding included health problems of babies ${ }^{9}$.

In this study, which compared the initiation and continuation of breastfeeding in babies who were born healthy and who were born with health problems, it was determined that $49.8 \%$ of the babies were born via caesarian section while $15.2 \%$ of them were born prematurely (before the 37th week of pregnancy). It was also determined that $17.2 \%$ of them $(<2500 \mathrm{~g})$ were born with low birth weights while 19.8\% of them had health problems after birth. In TNSA 2018 data, it was reported that the caesarian section rate in Turkey was $52 \%$ while the rate of low birth weight $(<2500 \mathrm{~g})$ was $12 \%$. However, no rate for babies who were born prematurely was reported ${ }^{10}$. In other studies conducted in Turkey, the rate of premature births varied between $13.6 \%$ and $17.3 \% 11,12$. Globally, approximately $11.1 \%$ of the babies who were born alive in 2010 were born prematurely (before the 37th week of pregnancy) and this rate was reported to be increasing in many countries ${ }^{13}$. In another study conducted in Turkey, it was reported that the rate for babies who were born with health problems at the time of birth was $11.1 \% 14$. The fact that this study was conducted in a tertiary level hospital, which followed up and treated patients, who came from cities in the vicinity and especially with chronic diseases, was believed to be a reason for higher the rates for 
babies born with preterm, low birth weight and health problems compared to other studies.

In studies that evaluated the status of breastfeeding in babies who were born prematurely, with low birth weights and with health problems after birth, various results were reported. In a qualitative study conducted in China, it was determined that the mothers of babies who were born prematurely defined their breastfeeding experiences in the periods when they were separated from their babies as physically and mentally challenging 15 .In a study conducted by Sahin et al.16 it was determined that the low birth weight of babies increased the concern about insufficient milk secretion twofold. In a prospective cohort study, it was determined that being admitted to premature and newborn service affected the initiation of breastfeeding and breastfeeding period negatively ${ }^{17}$. Hakala et al. ${ }^{18}$ in their study conducted in Finland, determined that $75 \%$ of all of the mothers started breastfeeding successfully and breastfeeding success was lower in babies with low Apgar score and those who were born in the 36th week of pregnancy. In this study, the rates for initiation of breastfeeding within the first hour for babies who were born with health problems and feeding with breast milk as the first food were significantly lower compared to babies who were born healthy, which was similar to other studies.

In a study conducted in China, it was reported that $25 \%$ of preterm infants were only fed with breast milk in six months while the fact that the period of mother-baby separation was low in the intensive care unit and the higher week of pregnancy were among the factors that increased this rate ${ }^{19}$. Roostaee et al. ${ }^{20}$ was determined that babies' health problems were significant factors in stopping breastfeeding within the first six months. In a study conducted by Unsal et al. ${ }^{14}$ was reported that the presence of health problems at birth was a negative factor that affected only breast milk intake in the first 6 months and the rate for being fed with breast milk in the first 6 months was $26 \%$ for babies who were born with health problems. In our study, the rate for being fed with only breast milk in the first 6 months was $22 \%$, which was observed to be similar to the results of other studies.

In this study, it was determined that $31.9 \%$ of the babies who were reported to have health problems after birth were fed with baby formula within the first month and a majority of them (73.6\%) used feeding bottles. In a study, it was reported that $50 \%$ of newborns, who were discharged to houses from newborn care units did not receive breast milk $^{21}$. In another study, it was reported that using baby formulas in the hospital increased the risk of stopping breastfeeding within the first month ${ }^{22}$. Gianni et $\mathrm{al}^{23}$. in their study conducted on a newborn care unit, reported that the rate for babies being fed only with breast milk was $27 \%$ while difficulties in obtaining breast milk by pumping and providing sufficient breast milk increased the risk of being fed with baby formulas. The results of our study and other studies revealed that the risk of being fed with baby formula was increased in babies who had health problems after birth and who were hospitalized.

Limitations of the study: This study investigated the health problems of babies after birth by open-ended questions to mothers; however, health problems were not categorized due to lack of replies or insufficient statements of mothers and were not evaluated separately. In the study, another limitation is the fact that there were no data regarding Apgar scores, the place of delivery, the period of staying in the hospital after birth, the period of separation of mother and baby, receiving support from healthcare personnel, giving baby formula in the hospital and giving milk by pumping. Additionally, because this study was 
conducted in a single tertiary level hospital, the results of the study cannot be generalized.

\section{CONCLUSION}

This study determined that being born with health problems delayed initiation of being fed by breastfeeding while increasing the risk of being fed with baby formula within the first month and the first six months as well as affecting the continuation of breastfeeding negatively. The mothers of babies who are born with health problems should be provided by healthcare specialists with specific information, help and support in terms of initiating and continuing feeding with breast milk.

Ethics Committee Approval: Ethical committee approval was obtained from the Faculty of Medicine at Gaziantep University prior to the study (Decision no: 2019/18).

Declaration of Conflicting Interests: The authors declare that they have no conflict of interest.

Financial Disclosure: No financial support was received.

\section{REFERENCES}

1. Nkoka O, Ntenda PAM, Kanje V, Milanzi EB, Arora A. Determinants of timely initiation of breast milk and exclusive breastfeeding in Malawi: a population-based cross-sectional study. Int Breastfeed J. 2019; 14: 37.

2. World Health Organization. Infant and Young Child Nutrition; Global Strategy on Infant and Young Child Feeding. 2002: Geneva: WHO.

3. Akova S, Yazar AS, Güven S, et al. Evaluation of growth and development in breast-fed infants throughout 0-36 months. Dicle Med J. 2012; 39: 542-6.

4. Pinchevski-Kadir S, Shust-Barequet S, Zajicek M, et al. Direct Feeding at the Breast Is Associated with Breast Milk Feeding Duration among Preterm Infants. Nutrients. 2017; 9: 1202.
5. Dewey KG. Maternal and fetal stress are associated with impaired lactogenesis in humans. J Nutr. 2017; 131: 3012S-3015S.

6. Leeman KT, Barbas K, Strauss J, et al. Improving Access to Lactation Consultation and Early Breast Milk Use in an Outborn NICU. Pediatr Qual Saf. 2019; 4: e130.

7. Rodrigo R. Amir LH. Forster DA. Review of guidelines on expression, storage and transport of breast milk for infants in hospital, to guide formulation of such recommendations in Sri Lanka. BMC Pediatr. 2018; 18: 271.

8. Lau C.Breastfeeding Challenges and the Preterm Mother-Infant Dyad: A Conceptual Model. Breastfeed Med. 2018; 13: 8-17.

9. Odom EC, Li R, Scanlon KS, Perrineb CG, Grummer-Strawn L. Reasons for earlier than desired cessation of breastfeeding. Pediatrics. 2013; 131: e726-e732.

10. Hacettepe Üniversitesi Nüfus Etütleri Enstitüsü. 2018 Türkiye Nüfus ve Sağlık Araștırması. Hacettepe Üniversitesi Nüfus Etütleri Enstitüsü, T.C. Cumhurbaşkanlığı Strateji ve Bütçe Başkanlığı ve TÜBİTAK, 2019. Ankara, Türkiye. (in Turkish)

Available

from: http://www.hips.hacettepe.edu.tr/tnsa2018/rapo r/TNSA_2018_anarapor.pdf (Accessed on 20.11.2019) (in Turkish)

11. Bülbül A, Keskin LŞ, Zubarioglu AU, et al. Doğumhanede yenidoğan bebeklerin izlem süreçleri: İki yıllık istatistiksel değerlendirme. Șișli Etfal Tıp Bülteni 2017; 51: 191-4. (in Turkish)

12. Ege E, Akın B, Altuntuğ K, Arıöz A, Koçoğlu D.Prevelance of Spontaneus Preterm Birth and Related Factors. J Turk Soc Obstet Gynecol. 2009; 6: 197-205.

13. Blencowe $\mathrm{H}$, Cousens $\mathrm{S}$, Chou $\mathrm{D}$, et al. Born too soon: the global epidemiology of 15 million preterm births. Reprod Health. 2013; 10 Suppl 1(Suppl 1): S2.

14. Unsal H, Atlıhan F, Özkan H, Targan S, Hassoy H.Toplumda anne sütü verme eğilimi ve buna etki eden faktörler. Çocuk Sağlığı ve Hastalıkları Dergisi. 2005; 48: 226-33. (in Turkish) 
15. Yang Y, Brandon D, Lu H, Cong X.Breastfeeding experiences and perspectives on support among Chinese mothers separated from their hospitalized preterm infants: a qualitative study. Int Breastfeed J. 2019; 14:1-7.

16. Sahin H. Yılmaz H, Aykut M, Balcı E, Sağıroğlu M, Öztürk A.Risk factors for breastfeedingproblems in mothers who presented to two public healthcare centers in Kayseri province. Turk Pediatri Arsiv. 2013; 48145-7.

17. Ladomenou F, Kafatos A, Galanakis E.Risk factors related to intention to breastfeed, early weaning and suboptimal duration of breastfeeding. Acta Paediatr. 2007; 96: 1441-4.

18. Hakala M, Kaakinen P, Kääriäinen M, Bloigu R, Hannula L, Elo S.The realization of BFHI Step 4 in Finland - Initial breastfeeding and skin-to-skin contact according to mothers and midwives. Midwifery. 2017; 50: 27-35.
19. Wang $\mathrm{Y}$, Briere $\mathrm{CE}, \mathrm{Xu} \mathrm{W}$, Cong X.Factors Affecting Breastfeeding Outcomes at Six Months in Preterm Infants. J Hum Lact. 2019; 35: 80-89.

20. Roostaee F, Tabatabaei SM, Zaboli M,et al.Breast-feeding Continuation in South-Eastern of Iran: the Associated Factors. Med Arch. 2015; 69: 98-102.

21. Power NG, Bloom B, Peabody J, Clark R.Site of Care Influences Breastmilk Feedings at NICU Discharge. J Perinatol.2013; 23: 10-3.

22. Chantry CJ, Dewey KG, Peerson JM, Wagner EA, Nommsen-Rivers LA. In-hospital formula use increases early breastfeeding cessation among firsttime mothers intending to exclusively breastfeed. J Pediatr. 2014; 164: 1339.

23. Gianni ML, Bezze EN, Sannino P, et al. Maternal views on facilitators of and barriers to breastfeeding preterm infants. BMC Pediatr. 2018; 18: 283. 